\title{
PENGARUH JARAK ANTARKAWAT TERHADAP EFISIENSI PENUKAR PANAS JENIS PEMBULUH DAN KAWAT KONVEKSI BEBAS
}

\author{
(THE INFLUENCE OF WIRE PITCH TO THE WIRE AND TUBE HEAT EXCHANGER \\ EFFICIENCY IN FREE CONVECTION)
}

\author{
I Made Arsana \\ Fakultas Teknik Universitas Negeri Surabaya \\ Jl. Ketintang Baru XII No. 34, Ketintang, Gayungan, Surabaya \\ e-mail: madearsana@unesa.ac.id
}

\begin{abstract}
Abstrak
Alat penukar panas jenis pembuluh dan kawat terdiri atas pembuluh (tube) yang dibuat berlekuk-lekuk (coil), dengan kawat (wire) yang dipasang lekat pada kedua sisinya dalam arah normal pada pembuluh. Kemampuan penukar panas ini dalam membuang panas ditunjukkan oleh efisiensi permukaan menyeluruh (overall surface efficiency) dari susunan sirip atau disebut sebagai efisiensi penukar panas. Kawat yang berfungsi sebagai sirip adalah perluasan dari permukaan luar pembuluh sehingga memperluas permukaan perpindahan panas konveksi bebas dari penukar panas ke lingkungan luar. Efisiensi sirip secara umum tergantung pada bahan sirip, geometri sirip dan lingkungan dimana sirip itu digunakan. Pada penelitian ini dikaji secara eksperimental pengaruh jarak antarkawat terhadap efisiensi penukar panas, tiga desain penukar panas dengan jarak antarkawat yang berbeda $(\mathrm{pw} / \mathrm{Lw}=0,015 ; \mathrm{pw} / \mathrm{Lw}=0,029$ dan $\mathrm{pw} / \mathrm{Lw}=$ 0,044) diuji dalam lima level suhu fluida masuk $\left(40,50,60,70\right.$, dan $\left.80{ }^{\circ} \mathrm{C}\right)$. Diperoleh hasil, penukar panas dengan $\mathrm{pw} / \mathrm{Lw}=0,029$ secara rata-rata menghasilkan efisiensi yang tertinggi.
\end{abstract}

Kata kunci: efisiensi penukar panas, jarak antarkawat, penukar panas jenis pembuluh dan kawat, konveksi bebas

\begin{abstract}
Wire and Tube heat exchanger consists of coiled tube and wire sticked on the two sides of it in normal direction of the tube. The ability of this heat exchanger to dissipate heat is shown by the overall surface efficiency from array of fins or called as heat exchanger efficiency. The wire which functions as a fin is the expansion of the outer surface of tube, so that it expands the surface of free convection heat transfer and transfers heat from the heat exchanger to the outside surroundings. The fin efficiency commonly depends on its material, geometry and environment where it is used. In this research, the influence of the wire pitch to the heat exchanger was examinated. Tthree designs of the heat exchanger with different wire pitch namely ( $\mathrm{pw} / \mathrm{Lw}$ $=0.015 ; \mathrm{pw} / \mathrm{Lw}=0.029 \mathrm{dan} \mathrm{pw} / \mathrm{Lw}=0.044)$ were tested into five levels of entrance fluids temperature $\left(40,50,60,70\right.$, and $\left.80^{\circ} \mathrm{C}\right)$. The finding of this study was that the heat exchanger $p w / L w=0.029$ evenly produced the highest efficiency.
\end{abstract}

Keywords: heat exchanger efficiency, pitch of wire, wire and tube heat exchanger, free convection 


\section{PENDAHULUAN}

Alat penukar panas merupakan suatu peralatan yang digunakan untuk mempertukarkan energi dalam bentuk panas antara aliran fluida yang berbeda suhu yang dapat terjadi melalui kontak langsung maupun tidak langsung (Mendez, Sen, Yang, \& McClain, 1999). Salah satu aplikasi dari prinsip pertukaran panas adalah pada penukar panas jenis pembuluh dan kawat (wire and tube exchangers). Penukar panas pembuluh dan kawat terdiri dari pembuluh koil dan kawat yang dilas atau dipasang pada pembuluh dengan arah normal dan saling berhadapan. Penukar panas ini termasuk jenis penukar panas permukaan diperluas (extended surface). Kawat yang berfungsi sebagai sirip dipasang lekat pada pembuluh yang mengalirkan fluida panas dengan tujuan untuk meningkatkan luas permukaan perpindahan panas dan selanjutnya akan memperbesar laju perpindahan panas (Kumra, Rawal, \& Samui, 2013). Secara mekanis, kawat juga berfungsi memperkuat konfigurasi pembuluh yang dibuat berlekuklekuk (coil).

Wire dan tube condenser ini sangat berperan penting dalam efisiensi kerja maupun biaya operasi mesin kulkas. Bentuk dan spesifikasi geometri alat sangat menentukan besarnya panas yang dapat dipindahkan ke lingkungan. Jarak antarkawat, diameter kawat, diameter pembuluh, dan jarak antarpembuluh pada alat merupakan parameter desain yang sering diubah-ubah untuk mendapatkan perpindahan panas yang optimum antara refrigerant dengan lingkungan (Patil, Mali, \& Ojha, 2012)

Penukar panas ini telah digunakan secara luas untuk membuang panas dari fluida panas yang mengalir melalui pembuluh sebagai kondensor pada alat sistem refrigerasi udara yang kecil (lemari es) untuk mengkondensasi fluida yang mengalir pada pembuluh atau diaplikasikan hanya sebagai pendingin (cooler) fluida yang mengalir dalam pembuluh tanpa terjadi perubahan fase (Samana, Kiatsiriroat, \& Nuntaphan, 2012). Namun demikian, kajian mengenai unjuk kerja dari penukar panas ini dalam membuang panas belum banyak dilakukan. Salah satu karakteristik unjuk kerja dari penukar panas adalah efisiensi penukar panas. Efisiensi penukar panas jenis pembuluh dan kawat, tidak lain adalah efisiensi permukaan menyeluruh (overall surface efficiency) dari susunan sirip (array of fins). Efisiensi sirip dalam memindahkan panas didefinisikan sebagai perbandingan antara laju perpindahan panas oleh sirip dengan laju perpindahan panas maksimum yang ideal. Laju perpindahan panas oleh sirip akan mencapai maksimum apabila 
seluruh permukaan sirip berada pada suhu dasar sirip. Dengan adanya tahanan termal konduksi di dalam sirip menyebabkan terjadinya gradien suhu sehingga suhu ujung sirip lebih kecil dari suhu dasar sirip. Hal ini menyebabkan pengurangan laju perpindahan panas yang terjadi, efisiensi sirip menurun dan akhirnya efisiensi penukar panas juga menurun (Cengel, 1998). Efisiensi sirip secara umum tergantung pada bahan sirip dan lingkungan sirip itu digunakan.

Faktor lain yang mempengaruhi efisiensi sirip adalah geometri sirip karena geometri kawat (sirip) berhubungan dengan luas permukaan perpindahan panas, yang merupakan salah satu faktor yang mempengaruhi besarnya laju perpindahan panas. Faktor geometri sirip menjadi lebih penting karena aplikasi dari penukar panas jenis pembuluh dan kawat digunakan pada kondisi konveksi bebas, koefisien konveksinya relatif kecil sehingga untuk meningkatkan laju perpindahan panas melalui penukar panas dapat dilaksanakan dengan meningkatkan luas permukaan perpindahan panas (Srinivasan \& Shah, 1997). Namun, dalam usaha untuk meningkatkan luas permukaan perpindahan panas (S) dengan menambah jumlah kawat-kawat, harus diupayakan agar koefisien perpindahan panas konveksi bebas (h) tidak sampai terganggu (Incropera, 1996). Jadi faktor geometri yang tepat/optimal merupakan interaksi antara koefisien perpindahan panas (h) dan luasan permukaan perpindahan panas (S). Beranjak dari pemikiran-pemikiran di atas, studi ini dilaksanakan.

Penelitian menyangkut penukar panas jenis pembuluh dan kawat, pertama kali dilakukan oleh Witzel dan Fontaine di tahun 1957 tentang karakteristik perpindahan panas pada kondensor jenis pembuluh dan kawat dan tentang desain kondensor pembuluh dan kawat yang menghasilkan persamaan nusselt empiris sebagai fungsi dari bilangan grashoft yaitu $N u=0,4724(G r)^{0,2215}$. Penelitian serupa dilakukan oleh Cyphers, Cess, dan Somers pada tahun 1959 tentang karakter perpindahan panas pada penukar panas pembuluh dan kawat. Penelitian tentang evaluasi film konveksi pada penukar panas jenis pembuluh dan kawat juga dilakukan oleh Witzel, Fontaine, dan Papanek tahun 1959. Penelitian Collicott, Fontaine, dan Witzell dilakukan tahun 1963 tentang perpindahan panas konveksi bebas dan radiasi pada penukar panas jenis pembuluh dan kawat. Kontribusi berikutnya dilakukan oleh Tagliafico dan Tanda (1997) tentang perpindahan panas konveksi bebas pada penukar panas jenis pembuluh dan kawat, dengan menggunakan air sebagai fluida kerja dalam pembuluh. Studi eksperimen tersebut bertujuan untuk mempresentasikan 
korelasi perpindahan panas konveksi bebas dari permukaan luar penukar panas ke udara sekeliling.

Kumara (2011) melakukan optimasi terhadap domectic condenser yaitu model NST200 dengan menggunakan model yang telah dikembangkan oleh Tagliafico dan Tanda (1997) yang bertujuan untuk meningkatkan perpindahan panas dan mengurangi biaya pembuatan condenser. Hasilnya menunjukkan bahwa modified condenser dapat meningkatkan perpindahan panas sebesar 32,9\% dan mengurangi biaya produksi sebesar 19\% dari desain yang sudah ada (present condenser).

Perkembangan terakhir mengenai studi menggunakan objek penukar panas ini, Boulahrouz dan Haddouche (2014) melakukan studi analisis numerik terhadap performa penukar panas pembuluh dan kawat yang diaplikasikan pada pendinginan elektronik. Pengaruh kondisi operasi seperti temperatur lingkungan dan laju aliran massa fluida disimulasikan pada kondisi konveksi bebas dan paksa, dengan menggunakan fluida kerja FC-72 dan PF-5060.

Dari beberapa penelitian tersebut dapat dilihat bahwa peneliti yang telah melakukan kajian terhadap penukar panas jenis pembuluh dan kawat, secara umum mencari korelasi perpindahan panas dalam bentuk persamaan nusselt empiris dengan tujuan untuk dapat mengevaluasi nilai koefisien perpindahan panasnya (h). Penelitian ini dilakukan dengan tujuan untuk menganalisis pengaruh geometri kawat khususnya jarak antarkawat terhadap efisiensi penukar panas jenis pembuluh dan kawat.

Penukar panas jenis pembuluh dan kawat (wire and tube heat exchanger) terdiri dari pembuluh horisontal (sebagai tempat mengalirnya fluida panas) yang dibuat berlekuk-lekuk dalam susunan vertikal, dengan kawat yang dilekatkan pada kedua sisinya dalam arah normal pada pembuluh (Tanda \& Tagliafico, 1997). Dalam aplikasinya posisi pemasangan dari alat penukar panas ini adalah vertikal, seperti terlihat pada Gambar 1 (Kumra, Rawal, \& Samui, 2013).

Geometri kawat adalah panjang kawat (Lw) yang mengikuti tinggi dari penukar

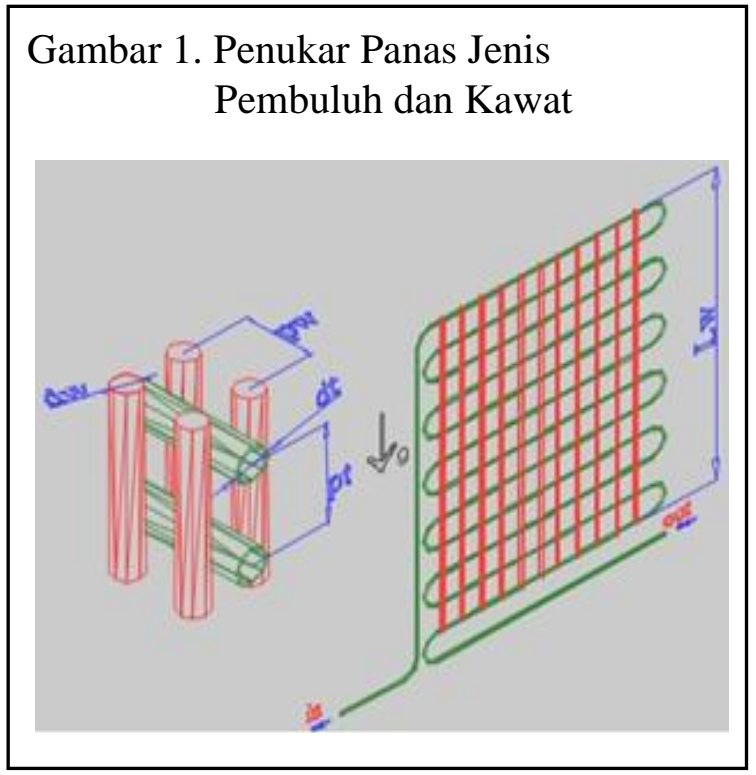


panas (tinggi susunan vertikal dari pembuluh horisontal), pitch/jarak antarkawat (pw) dan diameter kawat (dw). Penukar panas yang ditinjau menggunakan panjang kawat (Lw) didefinisikan sebagai tinggi penukar panas adalah $445 \mathrm{~mm}$ dengan tiga (3) variasi jarak antarkawat (pitch kawat) yaitu 6,5 mm; 13 mm; dan 19,5 mm. Kondisi operasi dari penukar panas ditunjukkan oleh variasi bilangan Rayleigh sebagai fungsi dari beda suhu antara suhu fluida masuk dengan udara $\operatorname{luar}\left(\mathrm{T}_{f, \dot{n}}-\mathrm{T}_{\infty}\right)$.

Minyak panas mengalir dari bak termostatik dan bersirkulasi secara tunak di dalam pembuluh penukar panas. Dari kesetimbangan energi secara keseluruhan untuk penukar panas, dapat dihitung panas yang dilepaskan oleh minyak panas sebagai: $q_{\text {tot }}=\dot{m} \cdot C p, f(T f$, in $-T f, o u t)$

dalam hal ini:

$\dot{m}=$ laju aliran minyak $\left[\frac{K g}{s}\right]$.
$C p, f=$ panas spesifik tekanan konstan $\left[\frac{J}{K g \cdot K}\right]$

Tf, in = suhu minyak pada saluran masuk penukar panas $[K]$

Tf ,out $=$ suhu minyak pada saluran keluar penukar panas $[K]$

Efisiensi sirip dalam memindahkan panas didefinisikan sebagai perbandingan antara laju perpindahan panas oleh sirip dengan laju perpindahan panas maksimum yang terjadi jika seluruh permukaan sirip berada pada suhu dasar sirip (Kundu \& Das,
1999). Secara umum dirumuskan sebagai berikut:

$$
\eta_{f}=\frac{q_{f}}{q_{m a k}}=\frac{h \cdot S_{w}\left[T_{w}-T \infty\right]}{h \cdot S_{w}\left[T_{t}-T \infty\right]}
$$

Jika efisiensi sirip dinyatakan dengan asumsi koefisien perpindahan panas seragam sepanjang permukaan penukar panas, maka didapatkan:

$\eta_{f}=\frac{\left(\mathrm{T} w-\mathrm{T}_{\infty}\right)}{\left(\mathrm{T} t-\mathrm{T}_{\infty}\right)}$

Persamaan tersebut digunakan untuk menghitung efisiensi sirip penukar panas jenis pembuluh dan kawat.

Efisiensi penukar panas jenis pembuluh dan kawat, tidak lain adalah efisiensi permukaan menyeluruh dari susunan sirip, yang digunakan untuk mendefinisikan unjuk kerjanya. Kreith dan Prijono (1986) mengemukakan efisiensi total dari permukaan yang bersirip dapat diperoleh dengan menggabungkan bagian permukaan yang tidak bersirip (unfinned area) yang berefisiensi $100 \%$ dengan luas permukaan sirip-sirip yang berefisiensi:

$$
\eta_{f} \cdot \eta_{o}=\eta_{f} \frac{S_{w}}{S_{\text {tot }}}+\frac{S_{t}}{S_{\text {tot }}}
$$

Keterangan:

$n_{f}=$ efisiensi sirip

$S_{t o t}=S_{w}+S_{t}$

$S_{\text {tot }}=$ luas permukaan perpindahan panas total

$S_{w}=$ luas permukaan perpindahan panas kawat/sirip 
$S_{w}=$ luas permukaan perpindahan panas tube (unfinned surface).

\section{METODE}

Penelitian tentang pengaruh jarak antarkawat terhadap efisiensi penukar panas jenis pembuluh dan kawat secara eksperimental ini menggunakan tiga (3) buah rancangan penukar panas dengan jarak antarkawat yang berbeda dengan minyak thermo 22 sebagai fluida kerja di dalam pembuluh.

Untuk melihat pengaruh jarak antarkawat terhadap efisiensi penukar panas jenis pembuluh dan kawat, diperlukan peralatan dan bahan yang disusun dalam rangkaian skematis peralatan eksperimen (Gambar 2).

Peralatan dan bahan untuk melakukan eksperimen terdiri atas: alat penukar panas jenis pembuluh dan kawat dengan tiga buah rancangan geometri, bak termostatik sebagai

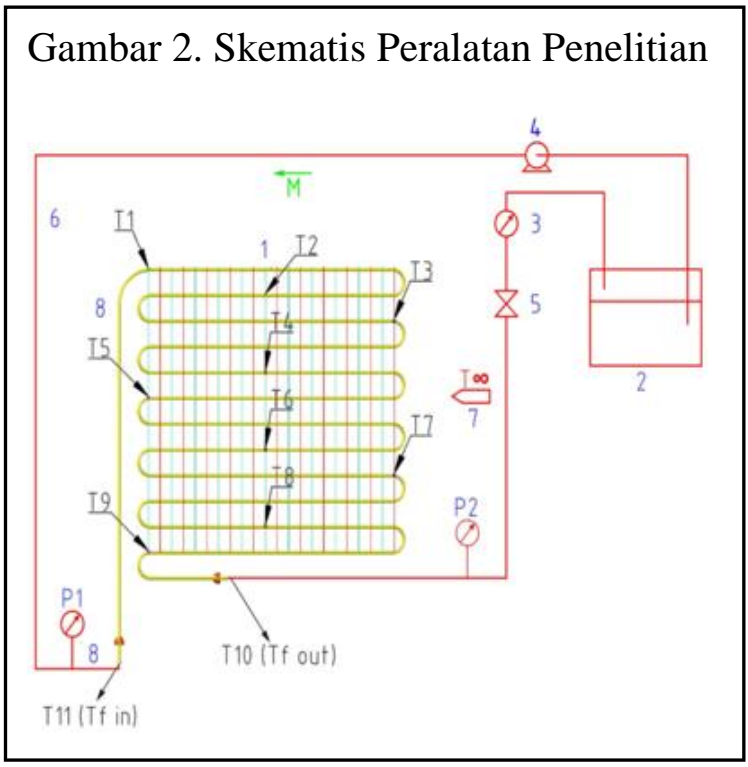

penampung dan memanaskan fluida sebelum dialirkan, flow meter, pompa sirkulasi, katup pengatur laju aliran fluida, pipa-pipa penghubung aliran, termometer pengukur suhu ruangan, thermocouple pengukur suhu permukaan kawat (Tw) dan suhu fluida di dalam pembuluh (Tf) untuk menentukan suhu tube (pembuluh) rata-rata (Tt), fluida kerja minyak pemindah panas thermo 22 , dan ruangan berisolasi dan terkondisi tetap.

Untuk mengukur suhu pada sejumlah titik, digunakan termokopel tipe $\mathrm{K}$ (CopperConstantan) yang dihubungkan dengan Suhu Display (CE 307) setelah melalui selektor 9 channel. Namun, sebelumnya dilakukan pengukuran distribusi temperatur pada permukaan penukar panas untuk melihat kecenderungan penurunan temperatur seanjang lintasan pembuluh menggunakan infrared themography.

\section{HASIL DAN PEMBAHASAN}

Sebagai langkah awal dalam penelitian ini dilakukan penjajakan awal kondisi distribusi temperatur permukaaan penukar panas dengan memetakan alat infrared thermography pada seluruh permukaan penukar panas. Dari hasil pengamatan dengan infrared thermography diperoleh gambaran awal distribusi temperatur yang disajikan pada Gambar 3.

Gambar 3 merupakan hasil foto infrared thermography yang menunjukkan 


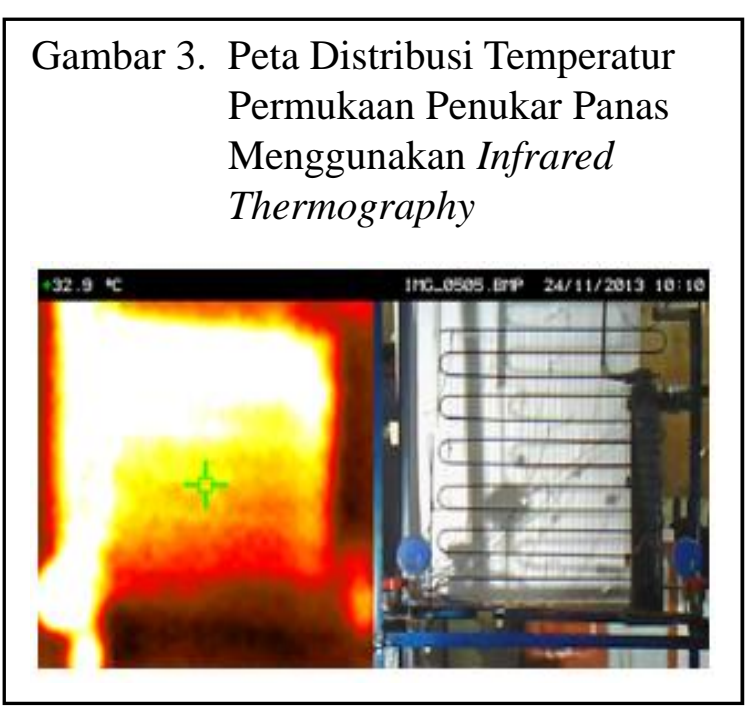

area panas permukaan penukar panas setelah dialirkan fluida panas (oli panas). Area warna putih merupakan bagian permukaan dengan temperatur tinggi (high temperature area) karena memang pada area itu merupakan bagian masuk fluida menuju penukar panas dimana temperatur fluida masih relatif tinggi. Selanjutnya, diikuti dengan area kekuningan yang merupakan medium temperature area yaitu bagian susunan kawat bagian tengah dari keseluruhan area permukaan penukar panas. Sebaran warna merah merupakan area dengan temperatur rendah (low temperature area) karena memang pada bagian tersebut fluida meninggalkan penukar panas. Dari gambaran awal ini dapat dilihat bahwa terjadi kecenderungan penurunan temperatur sejak fluida panas memasuki penukar panas dan terus menurun seiring dengan pelepasan panas yang dilakukan oleh susunan kawat-kawat yang berfungsi sebagai sirip sehingga akhirnya fluida dingin akan meninggalkan penukar panas.

Untuk melihat pengaruh jarak antarkawat terhadap efisiensi penukar panas jenis pembuluh dan kawat dilakukan perubahan terhadap bilangan Rayleigh sebagai fungsi dari beda suhu fluida masuk - udara luar $\left(\mathrm{T}_{f, \dot{i}}-\mathrm{T}_{\infty}\right)$, pertama dilakukan pengujian terhadap efisiensi fin. Hasilnya ditunjukkan pada Gambar 4, yang menampilkan pengaruh jarak antarkawat terhadap efisiensi sirip pada berbagai bilangan Rayleigh yang menunjukkan kondisi operasi penukar panas sebagai fungsi dari beda suhu fluida masuk udara luar (Tf,in - $\mathrm{T}_{\infty}$ ).

Dari Gambar 4 dapat dijelaskan bahwa secara umum dari ketiga penukar panas tersebut, efisiensi sirip dari penukar panas dengan $\mathrm{pw} / \mathrm{Lw}=0,029$ adalah yang tertinggi. Hal ini dapat dijelaskan dari analisis lapisan batas termal konveksi bebas (free convection thermal boundary layer) yang berkembang di sepanjang permukaan kawat-kawat. Bejan (1993) mengemukakan spasi kawat optimal terjadi bila lapisan batas panas berkembang sepanjang permukaan kawat (Lw) menjadi cukup tebal menyentuh trailing edge dari tiap sirip (kawat).

Dari Gambar 5 dapat dilihat, spasi kawat (jarak antarkawat) optimal terjadi bila lapisan batas termal yang berkembang dari masing-masing sirip, kemudian bergabung 


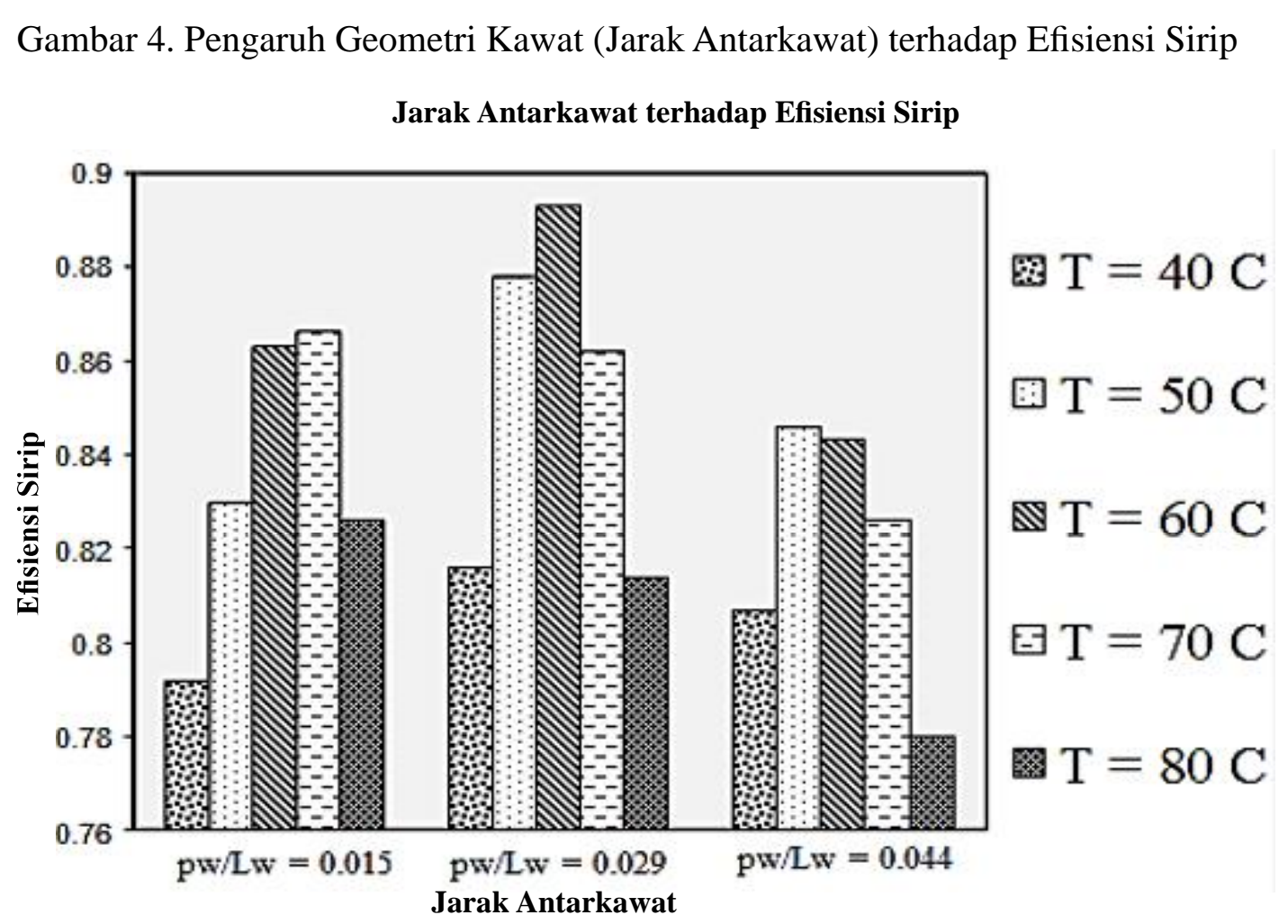

Gambar 5. Spasi Optimal dari Jarak Antarfin

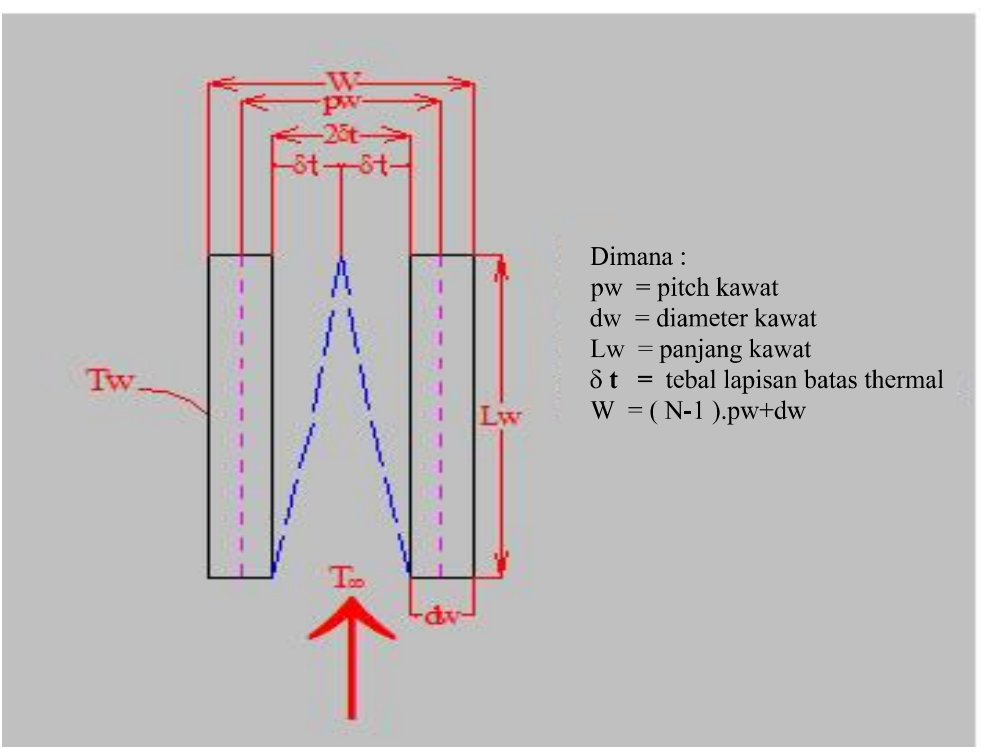


(merger) menjadi satu tepat pada ujung atas (trailing edge) dari kawat-kawat tersebut. Atau dapat ditulis dalam bentuk persamaan sebagai berikut:

$p w-d w=2 \delta t$

dalam hal ini:

$p w=$ pitch $\mathrm{kawat} / \mathrm{jarak}$ antarkawat (diukur

dari garis tengah antara kawat-kawat)

$d w=$ diameter kawat

$\delta t=$ tebal lapisan batas termal

Dari ketiga penukar panas tersebut, pada penukar panas dengan $\mathrm{pw} / \mathrm{Lw}=0,029$ tidak terjadi interaksi pada lapisan batasnya dan lapisan batas hampir bertemu pada trailing edge dari kawat-kawat, dengan demikian mempunyai luasan permukaan perpindahan panas $(\mathrm{S})$ yang cukup besar dengan tidak mengganggu koefisien perpidahan panasnya sehingga akhirnya penukar panas ini mempunyai efisiensi sirip yang paling tinggi.

Pada penukar panas dengan $\mathrm{pw} / \mathrm{Lw}$ $=0,044$ juga tidak terjadi interaksi pada lapisan batasnya, namun mempunyai pitch kawat yang lebih lebar sehingga interaksi lapisan batas akan terjadi jauh melewati trailing edge dari kawat dan akibatnya dalam lebar penukar panas yang telah ditentukan akan mempunyai jumlah kawat yang lebih sedikit bila dibandingkan dengan penukar panas dengan $\mathrm{pw} / \mathrm{Lw}=0,029$.
Penukar panas dengan pw/Lw $=0,015$ yang mempunyai $\mathrm{pw}=6,5 \mathrm{~mm}$ masih belum cukup untuk memberikan celah sebagai tempat berkembangnya lapisan batas sampai padaujung darikawat (trailing edge) sehingga terjadi interaksi pada lapisan batasnya (fully develoved flow). Diperkirakan lapisan batas bergabung pada jarak setengah dari tinggi penukar panas (dihitung dari leading edge). Hal ini terjadi karena penukar panas ini mempunyai spasi antarkawat $4,5 \mathrm{~mm}$; padahal kebutuhan spasi untuk menjamin lapisan batas bergabung tepat pada trailing edge dari kawat-kawat (spasi optimal) adalah $2 \delta t=8 \mathrm{~mm}$. Dengan berinteraksinya lapisan batas, mengakibatkan membesarnya tahanan perpindahan panas atau menurunkan koefisien perpindahan panas (h). Akhirnya menurunkan laju perpindahan panasnya, walaupun penukar panas ini mempunyai luasan permukaan perpindahan panas (S) yang paling besar. Menaikkan luas permukaan perpindahan panas (S) dengan mengurangi spasi antarkawat sampai menggangu koefisien perpindahan panasnya, tidak dapat menaikkan laju pembuangan panas secara berarti, hal ini berarti efisiensinya menurun (Incropera, 1996).

Bila dilihat dari penampilan efisiensi overall-nya, secara rata-rata penukar panas $\mathrm{pw} / \mathrm{Lw}=0,029$ dengan $\mathrm{pw}=13 \mathrm{~mm}$ mempunyai efisiensi yang paling tinggi. 


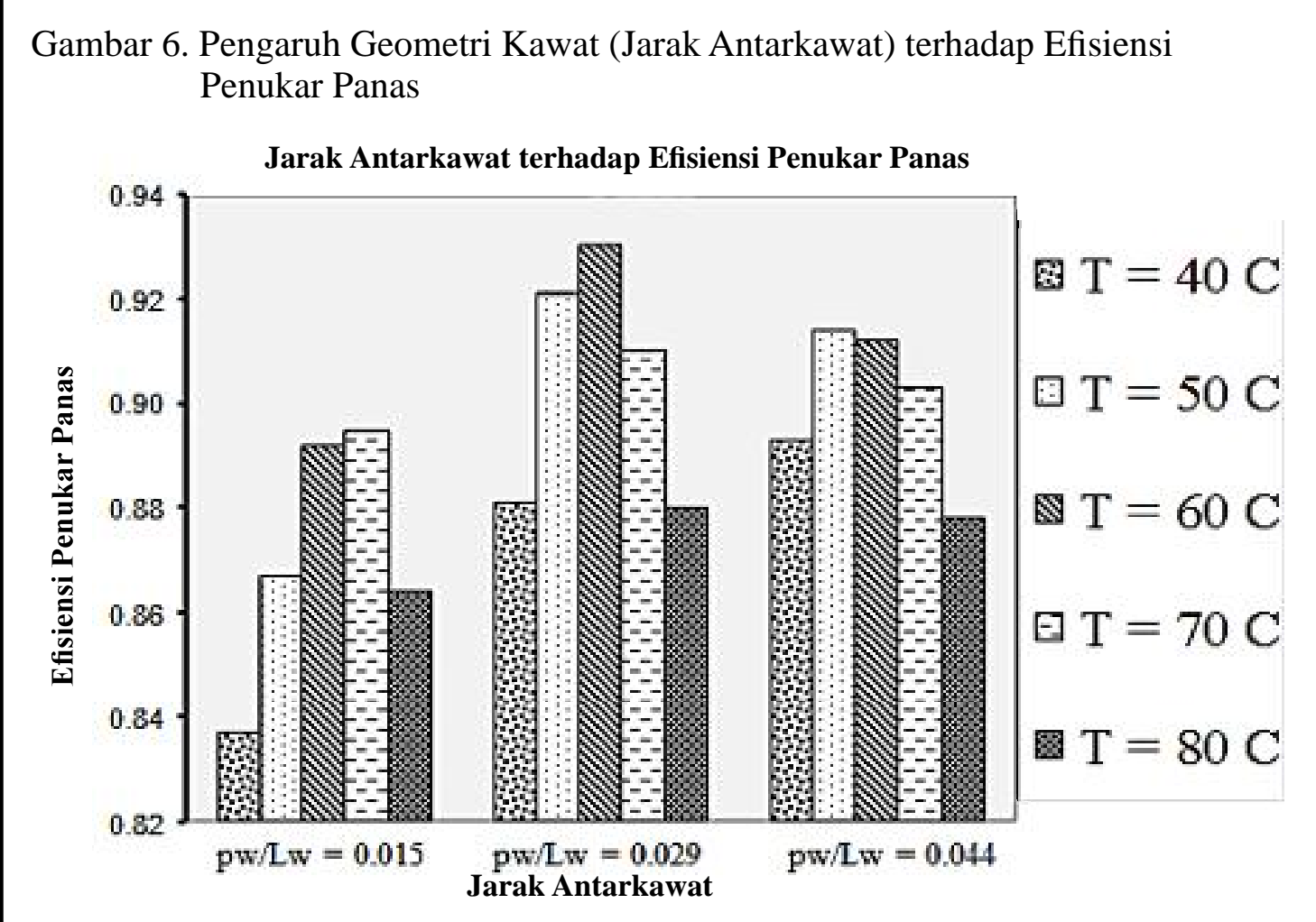

Diikuti oleh penukar panas $\mathrm{pw} / \mathrm{Lw}=0,044$ dengan $\mathrm{pw}=19,5 \mathrm{~mm}$ dan penukar panas $\mathrm{pw} / \mathrm{Lw}=0,015$ dengan $\mathrm{pw}=6,5 \mathrm{~mm}$, seperti ditampilkan Gambar 6.

Efisiensi permukaan menyeluruh menunjukkan efisiensi sirip dengan memperhitungkan faktor luasan sirip dan luasan tanpa sirip yang mempunyai efisiensi seratus persen. Bila suatu penukar panas dengan jumlah kawat lebih banyak dengan mengurangi spasi antarkawat maka bila efisiensi sirip turun, maka secara otomatis efisiensi overall sirip juga rendah karena luasan tanpa sirip menjadi lebih sedikit padahal luasan tanpa sirip ini yang mempunyai efisiensi $100 \%$, hal ini terjadi pada penukar panas $\mathrm{pw} / \mathrm{Lw}=0,015$. Penukar panas dengan efisiensi sirip tinggi dengan luasan tanpa sirip yang cukup (penukar panas $\mathrm{pw} / \mathrm{Lw}=0,029)$, akan mempunyai efisiensi overall yang tinggi. Selanjutnya, penukar panas $\mathrm{pw} / \mathrm{Lw}=0,044$ mempunyai efisiensi sirip yang rendah, akan tetapi mempunyai luasan tanpa sirip (efisiensi $100 \%$ ) yang besar maka akan mempunyai efisiensi overall yang cukup tinggi, namun nilainya masih di bawah penukar panas pw/ $\mathrm{Lw}=0,029$. 


\section{SIMPULAN}

Berdasarkan data hasil penelitian dan analisis yang dilakukan, dapat disimpulkan beberapa hal penting yang menyangkut efisiensi penukar panas jenis pembuluh dan kawat. Jarak antarkawat penukar panas mempengaruhi efisiensi penukar panas. Dari ketiga penukar panas tersebut, penukar panas $\mathrm{pw} / \mathrm{Lw}=0,029$ secara rata-rata mempunyai efisiensi tertinggi. Fluks panas $\left(\mathrm{W} / \mathrm{m}^{2}\right)$ tertinggi dilepaskan oleh penukar panas $\mathrm{pw} / \mathrm{Lw}=0,029$, kemudian berturut-turut penukar panas $\mathrm{pw} / \mathrm{Lw}=0,044 \mathrm{dan} \mathrm{pw} / \mathrm{Lw}=$ 0,015. Penambahan jumlah kawat (N) akan meningkatkan laju perpindahan panas dari penukar panas selama koefisien konveksi (h) tidak dipengaruhi oleh pengecilan pitch fin.

\section{DAFTAR PUSTAKA}

Bejan, A. (1993). Heat transfer. New York: John Willey \& Sons.

Boulahrouz, S., \& Haddouche, A. (2014). Finite volume analysis of a wire on tube heat exchanger used for cooling of electronics. International Journal on Heat and Mass Transfer Theory and Application (IREHEAT), 2(1).

Cengel, Y. A. (1998). Heat transfer a practical approach. New York: McGraw-Hill.

Incropera, F. P. (1996). Fundamentals of heat and mass transfer ( ${ }^{\text {rd }}$ ed.). New York: John Wiley \& Sons.
Kreith, F. (1997). Prinsip-prinsip perpindahan panas. (Terj.: Eko Prijono). Jakarta: Erlangga.

Kumara, P. (2011). Optimization of performance and assesment of material cost of the refrigerator condenser (Master of Science Thesis). KTH School of Industrial Engineering and Management, Stockholm.

Kumra, A. Rawal, N., \& Samui, P. (2013). Prediction of heat transfer rate of a wire-on-tube type heat eschanger: An artifical intelegence approach. Procedia Engineering, 64, 74-83.

Kundu, B., \& Das, P. K. (1999). Performance analysis and optimization of eccentric annular disk fins. Journal of Heat Transfer, 121, 419-429.

Mendez, R. R., Sen, M., Yang, K. T., \& McClain, R. (1999). Effect of fin spacing on convection in a plate fin and tube heat exchanger. International Journal of Heat and Mass Transfer, 43 (2000), 39-51.

Patil, K. S., Mali, K. V., \& Ojha, P. (2012). Simulation of wire and tubhe condenser of domestic refrigerator. International Jornal of Engineering and Sience Research (IJESR), 2(7), 613-620.

Samana, T., Kiatsiriroat, T., \& Nuntaphan, A. (2012). air-side performance analysis of a wire-on-tube heat exchanger with an oscillating heat pipe as an extended surface under natural convection conditions. Heat Transfer Engineering, 33(12), 1033-1039. 
Srinivasan, V., \& Shah, R. K. (1997). Fin efficiency of extended surfaces in two phase- flow. Journal of Heat and Fluid Flow, 18, 419-429.

Tagliafico, L., \& Tanda, G. (1997). Radiation and natural convection heat transfer from wire-and-tube heat exchangers in refrigeration appliances. International Journal of Refrigeration, 20(7), 461469.

Tanda, G., \& Tagliafico, L. (1997). free convection heat transfer from wire and tube heat exchangers. Journal of Heat Transfer. 119(2), 370-372. 